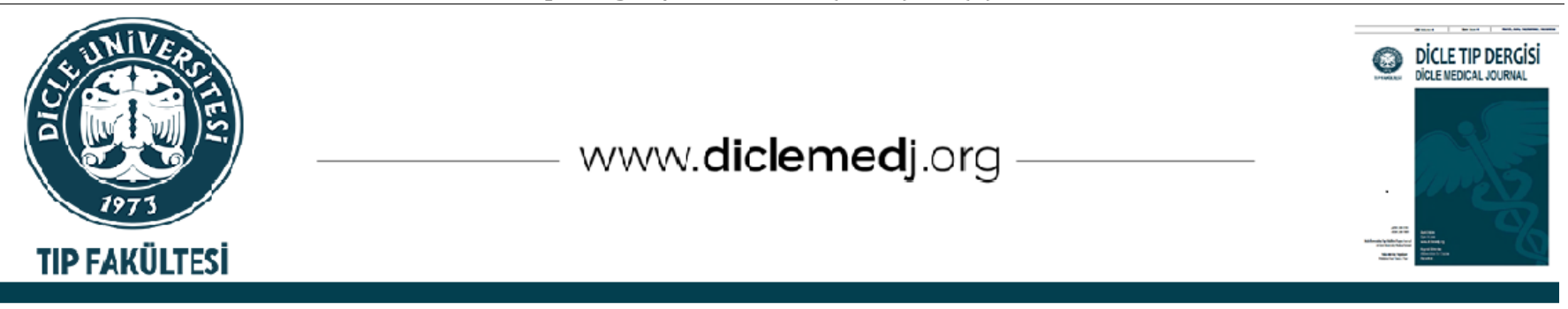

Original Article / Özgün Araştırma

\title{
Evaluation of Corneal Optic Quality in Amblyopia
}

\author{
Hasan Öncül ${ }^{\mathrm{D}}$ 1, Mehmet Fuat Alakus $\mathrm{iD}_{1}$ \\ 1 University of Health Sclences Diyarbakır Gazi Yasargil Training and Research Hospital Department of Ophthalmology. Diyarbakır, Turkey \\ Received: 27.11.2020; Revised: 20.01.2021; Accepted: 23.01.2021
}

\begin{abstract}
Objective: To compare corneal aberrations and densitometry values in children with amblyopia due to anisometropic hyperopia with those of healthy children.

Methods: This study included 173 children with amblyopia due to hyperopic anisometropia in one eye and 173 children with both healthy eyes. The amblyopic eye (Group 1) and the fellow normal eye (Group 2) of the amblyopic patients and the right eye of the healthy control group (Group 3) were evaluated. Of the corneal aberration and corneal densitometry (CD) measured using Scheimpflug corneal topography values were noted.
\end{abstract}

Results: While there was a significant difference in total root mean square (RMS), higher-order aberration (HOA) RMS, coma horizontal, trefoil horizontal and spherical aberration values between the groups $(p<0.001, p<0.001, p<0.001$, $\mathrm{p}<0.001, \mathrm{p}=0.008$, respectively), there was no difference between coma vertical and trefoil oblique values $(\mathrm{p}=0.076$, $\mathrm{p}=0.074$, respectively). There was no significant difference in terms of CD values in the anterior $0-2 \mathrm{~mm}$ and $2-6 \mathrm{~mm}$ regions between the groups ( $\mathrm{p}=0.081, \mathrm{p}=0.054$,respectively). However, the difference between the groups in the central $(0-2 \mathrm{~mm}, 2-6 \mathrm{~mm})$ and posterior $(0-2 \mathrm{~mm}, 2-6 \mathrm{~mm})$ area was statistically significant $(\mathrm{p}<0.001, \mathrm{p}=0.009, \mathrm{p}=0.009, \mathrm{p}<0.001$, respectively). In addition, the difference between the groups in the total $0-2 \mathrm{~mm}$ and $2-6 \mathrm{~mm}$ area was statistically significant ( $\mathrm{p}=0.001, \mathrm{p}<0.001$, respectively).

Conclusions: Total HOA values were higher in amblyopic eyes compared to the fellow normal eye. Central and posterior corneal densitometry values were decreased in patients' amblyopic eyes compared to their fellow eye. This may be related to some compensation mechanisms and/or microstructural changes in the cornea.

Keywords: amblyopia, corneal densitometry, optic quality, Pentacam HR

DOI: 10.5798/dicletip.887261

Correspondence / Yazıșma Adresi: Hasan Öncül, Department of Ophthalmology, University of Health Sciences, Diyarbakır Gazi Yaşargil Training and Research Hospital, Diyarbakır, Turkey e-mail: hasan.oncul@hotmail.com 


\section{Ambliyopide Korneal Optik Kalitenin Değerlendirilmesi}

Öz

Amaç: Anizometropik hipermetropiye bağlı ambliyopili çocuklarda korneal aberasyonları ve dansitometri değerlerini sağlıklı çocuklarla karşılaştırmak.

Yöntemler: Bu çalışmaya bir gözünde hipermetropik anizometropiye bağlı ambliyopi olan 173 çocuk ve her iki gözü sağlıklı 173 çocuk dahil edildi. Ambliyopik hastaların ambliyopik gözü (Grup 1), diğer normal gözü (Grup 2) ve sağlıklı kontrol grubunun sağ gözü (Grup 3) değerlendirildi. Scheimpflug korneal topografi kullanılarak ölçülen korneal aberasyon ve korneal dansitometri değerleri not edildi.

Sonuçlar: Gruplar arasında toplam kök ortalama kare, yüksek dereceli aberasyon kök ortalama kare, koma yatay, trefoil yatay ve sferik aberasyon değerlerinde anlamlı farklılı varken ( $<<0.001, p<0.001, p<0.001, p<0.001, p=0.008$; sırasıyla), koma dikey ve trefoil oblik değerleri arasında fark yoktu ( $p=0.076, p=0.074$; sirasıyla). Gruplar arasında ön 0-2 mm ve 2-6 mm bölgelerde korneal dansitometri değerleri açısından anlamlı fark yoktu $(\mathrm{p}=0.081, \mathrm{p}=0.054$; sirasıyla). Bununla birlikte, merkezi $(0-2 \mathrm{~mm}, 2-6 \mathrm{~mm})$ ve arka $(0-2 \mathrm{~mm}, 2-6 \mathrm{~mm})$ alanda gruplar arasındaki fark istatistiksel olarak anlamlıydı ( $<<0.001, p=0.009, p=0.009, p<0.001$; sirasıyla). Ayrıca toplam $0-2 \mathrm{~mm}$ ve 2-6 mm alanda gruplar arasındaki fark istatistiksel olarak anlamlıydı ( $\mathrm{p}=0.001, \mathrm{p}<0.001$; sırasıyla).

Tartışma: Ambliyopik gözlerde toplam yüksek dereceli aberasyon değerleri diğer normal göze göre daha yüksekti. Merkezi ve arka korneal dansitometri değerleri hastaların ambliyopik gözlerinde diğer gözlerine kıyasla azalmıştır. Bu korneadaki bazı kompansasyon mekanizmaları ve/veya mikroyapısal değişikliklerle ilgili olabilir.

Anahtar kelimeler: ambliyopi, korneal dansitometri, optik kalite, Pentacam HR.

\section{INTRODUCTION}

Amblyopia occurs in early childhood due to various visual disturbances, such as strabismus, anisometropia and deprivation, resulting in decreased contrast sensitivity and visual acuity ${ }^{1}$. Although it is often unilateral, it can also be bilateral. It is estimated that amblyopia affects $2.6 \%$ of preschool children and approximately $5 \%$ of the whole population ${ }^{2,3}$. Anisometropic amblyopia is caused by unequal cortical stimulations in both eyes due to uncorrected refractive error difference. Differences in refractive error between the two eyes may arise from differences in axial length or structural problems in the cornea ${ }^{4}$. Hypermetropia is common, especially in the pediatric age group. While mild anisometropic hyperopia rarely causes amblyopia, advanced disorders can lead to the development of amblyopia if not treated early.

The Pentacam HR (Oculus, Wetzlar, Germany) uses a rotating Scheimpflug camera to image the anterior ocular segment ${ }^{5}$. This imaging system can also be used to measure corneal densitometry (CD) data. This technique measures the reflected light intensity from the corneal epithelium, stroma and endothelium and provides fast and objective data to evaluate corneal transparency. This imaging method also allows the corneal aberrations affecting retinal image quality to be examined with the analysis of Zernicke's polynomials ${ }^{6}$.

Several studies in the literature have evaluated corneal aberrations in amblyopia ${ }^{7-8}$. However, to the best of our knowledge, there is no study investigating $\mathrm{CD}$ values in amblyopia. This study aimed to compare the corneal aberrations and $\mathrm{CD}$ analyses in children with amblyopia due to hyperopic anisometropia with those of children with two healthy eyes, matched for age and gender.

\section{METHODS}

This prospective observational study was conducted at the Gazi Yasargil Training and Research Hospital between January and September 2020. Local ethics committee 
approval was obtained from the aforementioned hospital. Written consent form was obtained from all participants. This study complied with the principles of the Helsinki Declaration.

This study included 173 children, aged 8-15 years, with amblyopia due to hypermetropia in one eye. All ophthalmologic examinations of their fellow eye were completely normal. The control group consisted of 173 healthy children with completely normal ophthalmologic examinations in both eyes. Children with amblyopia due to hyperopic anisometropia were selected from those who had no structural ocular abnormalities in either eye, refraction error due to hyperopia $\geq 1.5 \mathrm{D}$ in one eye, visual acuity less than 0.3 $\operatorname{logMAR}$. Refraction error in the fellow normal eye of these patients was less than $\pm 0.5 \mathrm{D}$ and visual acuity no less than $0.0 \log$ MAR. The healthy control group consisted of children who did not have structural ocular abnormalities in either eye, had a refraction error of less than $\pm 0.5 \mathrm{D}$ in both eyes, and had visual acuity of no less than 0.0 $\operatorname{logMAR}$ in both eyes. Group 1 was determined as the amblyopic eye of children with amblyopia, Group 2 as the fellow normal eye of amblyopic children, and Group 3 as the right eye of healthy children. Children with amblyopia due to strabismus, with decreased vision due to other ocular pathologies and who could not comply with the Pentacam HR were excluded from the study.

Visual acuity (logMAR), non-cycloplegic and cycloplegic refraction, indirect retinoscope, light biomicroscopic examination, and a detailed ophthalmologic examination, including a fundus examination, were performed. Refraction was measured with an auto refractometer (RKT-7700, NIDEK Co., Ltd., Gamagori, Japan). Endothelial cell counts were performed using a non-contact specular microscope (SP-3000P, Topcon Corporation, Tokyo, Japan). Central corneal thickness values measured with the Pentacam HR of all cases were also noted.

Measurements with the Pentacam HR for corneal topography analysis were performed in the same examination room (without windows), at the same time of day (between 14:00 and 16:00) without dilating the pupil. The automatic release mode of the Pentacam HR was used to minimize examiner-induced errors, and only good-quality images (based on the internal quality indicator of the Pentacam HR) were included. Three separate measurements were taken for all participants by the same researcher, and the best alignment and fixation were selected for the data analysis.

All higher-order aberration (HOA) measurements were taken in the same room. Each participant was asked to focus on the fixation goal before scanning. The best quality image was recorded. Then, the HOAs were analyzed using root mean square (RMS) values. Total HOA, spherical aberration, coma, and trefoil were obtained from each compartment with not dilated pupil.

Corneal densitometry as measured by the Pentacam HR is expressed in the arbitrary density units of corneal backscattered light. (0 greyscale units - maximum transparency, 100 greyscale units - minimum transparency) ${ }^{9}$. Corneal densitometry values are usually measured over a $6 \mathrm{~mm}$ diameter area in two concentric zones $(0-2$ $\mathrm{mm}$ and 2-6 $\mathrm{mm}$ ) within the area at three different layers (anterior, central, and posterior).

SPSS 17.0 software for Windows (SPSS Inc., Chicago, Illinois, USA) was used to analyse. Quantitative variables were reported as mean \pm standard deviation. A one-way analysis of variance (ANOVA) was used to compare the parameters of the three groups. The Bonferroni post hoc test was used to determine differences between the groups. The Bonferroni correction for post hoc analysis in ANOVA was performed; $p$ $<0.05 / 3=0.016$ was considered statistically significant. For other comparisons, $\mathrm{p}<0.05$ was considered statistically significant.

\section{RESULTS}

There were 94 boys and 79 girls in the amblyopic group, compared to 77 and 96 in the healthy group $(p=0.068)$. The children's mean age was $12.45 \pm$ 2.75 years in the amblyopic group and $12.47 \pm 2.62$ years in the healthy group $(\mathrm{p}=0.920)$.

There was no difference between the participants in terms of central corneal thickness and endothelial cells count ( $p=0.337, p=$ respectively). The spherical refraction value of the patients in Group 1 was 3.98 
$\pm 1.66 \mathrm{D}(1.50-7.75)$, while it was less than $\pm 0.5 \mathrm{D}$ in Groups 2 and 3. (Table 1) Total RMS (Group 1-2: $\mathrm{p}<0.001$, Group 1-3: $\mathrm{p}<0.001$, Group 2-3: $\mathrm{p}=$ 0.001), HOA RMS (Group 1-2: p< 0.001, Group 1-3: $\mathrm{p}<0.001$, Group 2-3: $\mathrm{p}=0.001$ ), coma horizontal (Group 1-2: $\mathrm{p}<0.001$, Group 1-3: $\mathrm{p}<0.001$, Group 23: $\mathrm{p}<0.001$ ), trefoil horizontal (Group 2-3: $\mathrm{p}<$ 0.001 ) and spherical aberration (Group 1-2: $\mathrm{p}=$

Table I: Central corneal thickness, corneal endothelial cell, spherical error, and corneal aberration measurements in amblyopic eye (Group 1), fellow normal eye (Group 2), and the healthy control group (Group 3)

\begin{tabular}{|c|c|c|c|c|c|}
\hline & Group 1 (n:173) & Group 2 (n:173) & Group 3 (n:173) & $P^{*}$ & $\begin{array}{l}P^{+} \\
\text {(Bonferroni post- } \\
\text { hoc) }\end{array}$ \\
\hline CCT $(\mu \mathrm{m})$ & $529.11 \pm 11.33$ & $530.14 \pm 9.53$ & $530.61 \pm 7.87$ & 0.337 & \\
\hline $\begin{array}{l}\text { Corneal endothelial cell } \\
\left(\text { cells } / \mathrm{mm}^{2}\right)\end{array}$ & $2962.05 \pm 117.14$ & $2937.62 \pm 108.26$ & $2950.13 \pm 121.00$ & 0.171 & \\
\hline Spherical error (D) & $\begin{array}{l}3.98 \pm 1.66(1.50- \\
7.75)\end{array}$ & $0.04 \pm 0.42(0-0.5)$ & $0.06 \pm 0.47(0-0.5)$ & $<0.001$ & $\begin{array}{l}1-2:<0.001 \\
1-3:<0.001 \\
1-2: 0.99\end{array}$ \\
\hline Total RMS $(\mu \mathrm{m})$ & $2.347 \pm 1.012$ & $1.406 \pm 0.427$ & $1.138 \pm 0.315$ & $<0.001$ & $\begin{array}{l}1-2:<0.001 \\
1-3:<0.001 \\
2-3: 0.001\end{array}$ \\
\hline HOA RMS $(\mu \mathrm{m})$ & $0.448 \pm 0.144$ & $0.389 \pm 0.097$ & $0.345 \pm 0.078$ & $<0.001$ & $\begin{array}{l}1-2:<0.001 \\
1-3:<0.001 \\
2-3: 0.001\end{array}$ \\
\hline Coma horizontal $(\mu \mathrm{m})$ & $0.059 \pm 0.228$ & $-0.035 \pm 0.153$ & $-0.131 \pm 0.091$ & $<0.001$ & $\begin{array}{l}1-2:<0.001 \\
1-3:<0.001 \\
2-3:<0.001\end{array}$ \\
\hline Coma vertical $(\mu \mathrm{m})$ & $0.002 \pm 0.196$ & $-0.037 \pm 0.185$ & $-0.031 \pm 0.115$ & 0.076 & \\
\hline Trefoil horizontal $(\mu \mathrm{m})$ & $0.024 \pm 0.152$ & $-0.007 \pm 0.096$ & $0.047 \pm 0.100$ & $<0.001$ & $\begin{array}{l}\text { 1-2: } 0.047 \\
\text { 1-3: } 0.203 \\
\text { 2-3: }<0.001\end{array}$ \\
\hline Trefoil oblique $(\mu \mathrm{m})$ & $-0.065 \pm 0.141$ & $-0.086 \pm 0.102$ & $-0.091 \pm 0.086$ & 0.074 & \\
\hline Spherical aberration $(\mu \mathrm{m})$ & $0.182 \pm 0.094$ & $0.206 \pm 0.068$ & $0.188 \pm 0.065$ & 0.008 & $\begin{array}{l}\text { 1-2: } 0.009 \\
\text { 1-3: } 0.99 \\
\text { 2-3: } 0.076\end{array}$ \\
\hline
\end{tabular}

CCT: Central corneal thickness D: Diopter RMS: Root mean square HOA: Higher-order aberration $\mu$ m: micron meters Results are denoted as mean \pm standard deviation *: One-way analysis of variance (ANOVA); $p<0.05$ statistically significant. + : Bonferroni Post Hoc test; $p<0.016$ statistically significant.
0.009 ) values were found to be statistically different between the groups. However, there was no significant difference in coma vertical and trefoil oblique values $(\mathrm{p}=0.076, \mathrm{p}=0.074$; respectively). The corneal aberration measurements for all participants are detailed in Table I. 0.171, 
In $\mathrm{CD}$ analysis, no significant difference was found between the groups in the anterior $0-2$ $\mathrm{mm}$ and anterior $2-6 \mathrm{~mm}$ regions $\mathrm{p}=0.081, \mathrm{p}=$ 0.054 , respectively). However, the difference between the groups in the central $(0-2 \mathrm{~mm}, 2-6$ $\mathrm{mm})$ and posterior $(0-2 \mathrm{~mm}, 2-6 \mathrm{~mm})$ area was statistically significant $(\mathrm{p}<0.001, \mathrm{p}=0.009, \mathrm{p}=$ $0.009, \mathrm{p}<0.001$, respectively). The total 0-2 $\mathrm{mm}$ region was measured as $14.14 \pm 0.78$ in Group 1 patients, $14.49 \pm 0.86$ in Group 2 patients, and $14.30 \pm 0.81$ in Group 3 patients (Group 1-2: $\mathrm{p}$ $<0.001$, Group 1-3: $\mathrm{p}=0.217$, Group 2-3: $\mathrm{p}=$ 0.113 ). The total $2-6 \mathrm{~mm}$ zone was measured as $12.82 \pm 0.68$ in Group 1, $13.11 \pm 0.72$ in Group 2, and $12.92 \pm 0.69$ in Group 3 (Group 1-2: $\mathrm{p}<$ 0.001, Group 1-3: $\mathrm{p}=0.522$, Group 2-3 $\mathrm{p}=$ 0.035 ). Corneal densitometry analysis of all cases are detailed in Table II.

Table II: Comparison of corneal densitometry values in amblyopic eye (Group 1), fellow normal eye (Group 2), and the healthy control group (Group 3)

\begin{tabular}{|c|c|c|c|c|c|}
\hline & $\begin{array}{l}\text { Group } 1 \\
(n: 173)\end{array}$ & $\begin{array}{l}\text { Group } 2 \\
\text { (n:173) }\end{array}$ & $\begin{array}{l}\text { Group } 3 \\
\text { (n:173) }\end{array}$ & $P^{*}$ & $\begin{array}{l}P^{\dagger} \\
\text { (Bonferroni post-hoc) }\end{array}$ \\
\hline $\begin{array}{l}\text { Anterior layer }(120 \mu \mathrm{m}) \\
\text { (GSUs) } \\
0-2 \mathrm{~mm} \\
2-6 \mathrm{~mm}\end{array}$ & $\begin{array}{l}19.81 \pm 1.41 \\
17.77 \pm 1.24\end{array}$ & $\begin{array}{l}20.01 \pm 1.32 \\
17.97 \pm 1.10\end{array}$ & $\begin{array}{l}20.14 \pm 1.40 \\
18.06 \pm 1.12\end{array}$ & $\begin{array}{l}0.081 \\
0.054\end{array}$ & \\
\hline $\begin{array}{l}\text { Central layer (GSUs) } \\
0-2 \mathrm{~mm} \\
2-6 \mathrm{~mm}\end{array}$ & $\begin{array}{l}12.30 \pm 0.62 \\
11.16 \pm 0.54\end{array}$ & $\begin{array}{l}12.72 \pm 0.65 \\
11.34 \pm 0.56\end{array}$ & $\begin{array}{l}12.47 \pm 0.74 \\
11.25 \pm 0.56\end{array}$ & $\begin{array}{l}<0.001 \\
0.009\end{array}$ & $\begin{array}{l}\text { 0-2 mm; } 2-6 \mathrm{~mm} ; \\
\text { 1-2: < } \mathbf{0 . 0 0 1} \text { 1-2: } \mathbf{0 . 0 0 7} \\
\text { 1-3: } 0.072 \text { 1-3: } 0.421 \\
\text { 2-3: } \mathbf{0 . 0 0 2} 2-3: 0.335\end{array}$ \\
\hline $\begin{array}{l}\text { Posterior layer } \\
(\mathbf{6 0} \boldsymbol{\mu m}) \text { (GSUs) } \\
0-2 \mathrm{~mm} \\
2-6 \mathrm{~mm}\end{array}$ & $\begin{array}{l}10.62 \pm 0.77 \\
9.77 \pm 0.67\end{array}$ & $\begin{array}{l}10.86 \pm 0.89 \\
10.02 \pm 0.77\end{array}$ & $\begin{array}{l}10.66 \pm 0.64 \\
9.78 \pm 0.50\end{array}$ & $\begin{array}{l}0.009 \\
<0.001\end{array}$ & $\begin{array}{l}\text { 0-2 mm; 2-6 mm; } \\
\text { 1-2: } \mathbf{0 . 0 1 3 ~ 1 - 2 : ~} \mathbf{0 . 0 0 1} \\
\text { 1-3: } 0.99 \text { 1-3: } 0.99 \\
\text { 2-3: } 0.053 \text { 2-3: } \mathbf{0 . 0 0 2}\end{array}$ \\
\hline $\begin{array}{l}\text { Total (GSUs) } \\
0-2 \mathrm{~mm} \\
2-6 \mathrm{~mm}\end{array}$ & $\begin{array}{l}14.14 \pm 0.78 \\
12.82 \pm 0.68\end{array}$ & $\begin{array}{l}14.49 \pm 0.86 \\
13.11 \pm 0.72\end{array}$ & $\begin{array}{l}14.30 \pm 0.81 \\
12.92 \pm 0.69\end{array}$ & $\begin{array}{l}0.001 \\
<0.001\end{array}$ & $\begin{array}{l}0-2 \mathrm{~mm} ; 2-6 \mathrm{~mm} ; \\
\mathbf{1 - 2}:<\mathbf{0 . 0 0 1} 1-2:<\mathbf{0 . 0 0 1} \\
1-3: 0.217 \text { 1-3: } 0.522 \\
\text { 2-3: } 0.113 \text { 2-3: } 0.035\end{array}$ \\
\hline
\end{tabular}

Results are denoted as mean \pm standard deviation GSU: Grayscale Units *: One-way analysis of variance (ANOVA); $p<0.05$ statistically significant. + : Bonferroni Post Hoc test; $p<0.016$ statistically significant.

\section{DISCUSSION}

In this study, total HOA values were found to be higher in amblyopic eyes compared to fellow eyes, and spherical aberration values were found to be lower. Although non-significant decreases were observed in the $C D$ values in the anterior areas of amblyopic eyes, the $\mathrm{CD}$ values in the central, posterior, and total region were significantly lower in amblyopic eyes than the fellow normal eyes.
Preservation of the transparent structure of the cornea is possible with a healthy complex interaction between the extracellular matrix and collagen. The homogeneous distribution of keratocytes, the organization of the collagen structure, the binding of proteoglycans and glycosaminoglycans to collagen fibres, corneal pressure and the production/destruction balance of extracellular matrix components are 
the main factors affecting corneal transparency ${ }^{10,11 .}$

In vivo confocal microscopy can provide images of the corneal tissue at various depths ${ }^{12}$. However, this technique is still not available in all centres, and there are difficulties in clinical practice. The Pentacam HR is a highly repeatable, reproducible, non-invasive imaging method that allows rapid and objective examination of the anterior segment ${ }^{13}$. With software added to this device, corneal transparency can be evaluated by densitometry measurement. In this way, variations in corneal density can be detected even in corneas that appear clinically clear.

Aberropia is defined as a refractive error that cannot be corrected with the combination of spheroid cylindrical lenses which named HOAs $^{14}$. The effect of HOAs on emmetropization and visual enhancement is still not fully understood. However, HOAs are thought to affect image quality in the retina ${ }^{15,16}$. Refractive errors of ocular structures may cause an increase in HOA, and this increase may result in the development of halo, distortion and glare.

Plech et al. found that total RMS values in the amblyopic eye of unilateral amblyopia were higher compared to the fellow normal eye. However, researchers reported that there was no difference between total RMS values in bilateral amblyopic patients and normal patients $^{14}$. It is well known that occlusion treatment is of great importance in amblyopia ${ }^{17}$. In a study by Lee et al. on anisometropic amblyopic children after amblyopia treatment, it was found that ocular spherical aberrations were higher in those who failed the treatment compared to the successful group. The authors reported that high HOA values were associated with failure ${ }^{7}$. In contrast to the above studies, Kirwan and O'Keefe reported that HOAs do not play a role in amblyopia ${ }^{8}$. In the present study, total HOA values were found to be significantly higher in the amblyopic eyes of amblyopic patients compared to the fellow normal eye and the healthy group's eyes. In addition, spherical aberration measurements were observed to be lower in the amblyopic eye compared to the fellow eye. It appears that, in anisometropic amblyopia, some structural changes may occur in the refractive components while maintaining the transparency of the eye. This may occur as differences in wavefront aberrations between the amblyopic eye and the fellow normal eye. These differences may lead to the development of amblyopia.

Another requirement for optimum vision is the presence of a transparent cornea. The researchers stated that $C D$ is an indicator of corneal transparency and health ${ }^{6}$. The increase in corneal density is not absolutely related to the decrease in vision. However, these increases are thought to be related to the decrease in quality of vision ${ }^{18}$. Light distribution is minimal in a healthy cornea ${ }^{6}$. Due to the differences in refractive indices, the highest light backscattering occurs in the anterior corneal epithelium and densitometry values of the anterior cornea. Since the posterior layer has less keratocyte density, the densitometry value is the lowest ${ }^{19}$.

Çankaya et al. reported that changes in spherical refraction did not affect $C D$ in healthy individuals aged 6-76 years ${ }^{20}$. Similarly, Garzon et al. stated that different spherical values did not affect $C D$ in healthy people between the ages of 20-5221. However, in these two studies, the refraction interval of the participants consisted of myopia and hyperopia (-6.5-5.0 D and -8.00$6.75 \mathrm{D}$, respectively). Also, all participants in these studies had $0.0 \log$ MAR. In contrast, current study consisted of hyperopic amblyopic patients only.

Collagen fibrils in the cornea are located more densely in the peripupillary cornea ${ }^{22}$. Researchers have reported a negative correlation between densitometry values and corneal diameter, and relate this to the different 
collagen sequences and extracellular matrix organization of the large corneas ${ }^{20}$. In addition, the repeatability and reproducibility of peripheral $C D$ measurements are low 9 . Therefore, in the present study, CD measurements were made from $0-2$ and 2-6 $\mathrm{mm}$ areas.

While we planning the current study, the question posed was whether there would be any change in $\mathrm{CD}$ values in any eyes in amblyopic children. If so, in which eye would this change occur? In this study, we observed a decrease in the anterior 0-2 $\mathrm{mm}$ and anterior 2$6 \mathrm{~mm}$ in the amblyopic eye, but this difference was not significant. The change in the refractive index of light in the anterior is highest, as the normal cornea distributes light predominantly at the air-tear film and tear-film corneal interface ${ }^{23}$. These results may be related to possible structural changes in the cornea except the air tear film and tear film corneal interface. We observed that there was a significant decrease in the amblyopic eye in the posterior $(0-2 \mathrm{~mm}$ and $2-6 \mathrm{~mm})$ and central $(0-2 \mathrm{~mm}$ and 2-6 $\mathrm{mm}$ ) area $\mathrm{CD}$ values compared to the fellow normal eye. In addition, a significant decrease was observed in the total area CD values in the amblyopic eye compared to the normal fellow eye. The reasons for this association remain unclear. Hayes et al. suggested that there are changes in the collagen sequence in the corneal stroma that may be due to eye movements that activate the extraocular rectus muscles and arouse counter-action forces in which the collagen fibres are aligned in different ocular refraction disorders ${ }^{24}$. The results of the current study may be due to a complex compensation mechanism that emerged to increase contrast sensitivity and visual quality in the low vision eye. In addition, the decrease in $C D$ values may be related to possible microstructural changes, such as keratocyte inhibition, remodelling of collagen fibres, and changes in the structure of the extracellular matrix in the corneal layers.
This study has some limitations. First, these results may be related to the fact that nonamblyopic eyes are completely healthy eyes. Similar studies should be conducted with patients with amblyopia who have decreased visual acuity in the fellow eye. Second, we were unable to provide the participants with in vivo confocal microscopy to support our findings, as it was not available. Possible microstructural changes in the cornea in amblyopia should be evaluated through in vivo confocal microscopic studies, and its relationship with CD should be investigated. Although the present study has drawn attention to changes in $\mathrm{CD}$ in amblyopic eyes, these results need to be supported by studies at cellular and histological levels.

Ethics Committee Approval: This prospective observational study was conducted at the Gazi Yasargil Training and Research Hospital between January and September 17.01.2020/418. Local ethics committee approval was obtained from the aforementioned hospital.

Declaration of Conflicting Interests: The authors declare that they have no conflict of interest.

Financial Disclosure: No financial support was received.

\section{REFERENCES}

1. Barrett BT, Bradley A, McGraw PV. Understanding the neural basis of amblyopia.

Neuroscientist. 2004; 10: 106-17.

2. Carlton J, Kaltenthaler E. Amblyopia and quality of life: a systematic review. Eye (Lond). 2011; 25: 40313.

3. Multi-ethnic Pediatric Eye Disease Study Group. Prevalence of amblyopia and strabismus in African American and Hispanic children ages 6 to 72 months the multi-ethnic pediatric eye disease study. Ophthalmology. 2008; 115: 1229-36.e1.

4. Wallace DK, Morse CL, Melia M, et al. Pediatric eye evaluations preferred practice pattern $®$. American academy of pediatric ophthalmology/strabismus 
preferred practice pattern pediatric ophthalmology panel. Ophthalmology. 2018; 125: 184-227.

5. Cho YK, Chang HS, La TY, et al. Anterior segment parameters using Pentacam and prediction of corneal endothelial cell loss after cataract surgery. Korean J Ophthalmol. 2010; 24: 284-90.

6. Otri AM, Fares U, Al-Aqaba MA, Dua HS. Corneal densitometry as an indicator of corneal health. Ophthalmology. 2012; 119: 501-8.

7. Lee SH, Chang JW. The relationship between higher-order aberrations and amblyopia treatment in hyperopic anisometropic amblyopia. Korean J Ophthalmol. 2014; 28: 66-75.

8. Kirwan C, O'Keefe M. Association between amblyopia and HOAs. J Cataract Refract Surg. 2007; 33: 1833-5.

9. Dhubhghaill SN, Rozema JJ, Jongenelen S, et al. Normative values for corneal densitometry analysis by Scheimpflug optical assessment. Invest Ophthalmol Vis Sci. 2014; 55: 162-8.

10. Meek KM, Leonard DW, Connon CJ, Dennis S, Khan S. Transparency, swelling and scarring in the corneal stroma. Eye (Lond). 2003; 17: 927-36.

11. Kling S, Hafezi F. Corneal biomechanics - a review. Ophthalmic Physiol Opt. 2017; 37: 240-52.

12. Daxer A, Misof K, Grabner B, Ettl A, Fratzl P. Collagen fibrils in the human corneal stroma: structure and aging. Invest Ophthalmol Vis Sci. 1998; 39: 644-8.

13. McAlinden C, Khadka J, Pesudovs K. A comprehensive evaluation of the precision (repeatability and reproducibility) of the Oculus Pentacam HR. Invest Ophthalmol Vis Sci. 2011; 52: 7731-7.

14. Plech AR, Pinero DP, Laria C, Aleson A, Alio JL. Corneal higher-order aberrations in amblyopia. Eur J Ophthalmol. 2010; 20: 12-20.
15. Applegate RA, Thibos LN, Hilmantel G. Optics of aberroscopy and super vision. J Cataract refract Surg. 2001; 27: 1093-107.

16. Kızlltoprak H, Koç M, Tekin K, et al. Evaluation of high-order corneal aberrations in children with well controlled type 1 diabetes mellitus. Dicle Med J. 2018; 45: 71-5.

17. Coşkun M, Doğan H, Öner AÖ. The effectiveness of occlusion treatment on anisometric amblyopia in different age groups. Dicle Med J. 2009; 36: 28-34.

18. Patel S, McLaren JW, Hodge DO, Bourne VM. The effect of corneal light scatter on vision after penetrating keratoplasty. Am J Ophthalmol. 2008; 146: 913-9.

19. Niederer RL, Perumal D, Sherwin T, McGhee CNJ. Age-related diferences in the normal human cornea: a laser scanning in vivo confocal microscopy study. Br J Ophthalmol. 2007; 91: 1165-9.

20. Cankaya AB, Tekin K, Kiziltoprak H, Karahan S, Yilmazbas P. Assessment of corneal backward light scattering in the healthy cornea and factors affecting corneal transparency. Jpn J Ophthalmol. 2018; 62: 335-41.

21. Garzón N, Poyales F, Illarramendi I, et al. Corneal densitometry and its correlation with age, pachymetry, corneal curvature, and refraction. Int Ophthalmol. 2017; 37: 1263-8.

22. Boote C, Dennis S, Newton RH, Puri H, Meek KM. Collagen fibrils appear more closely packed in the prepupillary cornea: optical and biomechanical implications. Invest Ophthalmol Vis Sci. 2003; 44: 2941-8.

23. O'Donnell C, Wolffsohn JS. Grading of corneal transparency. Cont Lens Anterior Eye. 2004; 27: 161-70.

24. Hayes S, Boote C, Lewis J, et al. Comparative study of fibrillar collagen arrangement in the corneas of primates and other mammals. Anat Rec (Hoboken). 2007; 290: 1542-50. 